\title{
The Effects of Modified Chitosan on the Physicomechanical Properties of Mortar
}

\author{
Lyazzat Bekbayeva1 ${ }^{*}$, El-Sayed Negim² ${ }^{2}$ Rimma Niyazbekova ${ }^{3}$, Zhanar Kaliyeva ${ }^{4}$, \\ Gulzhakhan Yeligbayeva ${ }^{5}$, J. Khatib ${ }^{6}$
}

${ }^{1}$ School of Chemical and Biological Technologies, Satbayev University, 22 Satpayev Street, 050013 Almaty, Kazakhstan

${ }^{2}$ Laboratory of Advanced Materials and Technology, Kazakh-British Technical University, 59 Tole bi St., 050000, Almaty, Kazakhstan

${ }^{3}$ Technical Faculty, Saken Seifullin Kazakh Agro Technical University, Astana, 010011, Zhenis avenue, 62, Kazakhstan

${ }^{4}$ Technology of Industrial and Civil Building, L.N. Gumilyov Eurasian National University, Str. Satpayev 2, Astana, Kazakhstan

${ }^{5}$ School of Petroleum Engineering, Satbayev University, 22 Satpayev Street, 050013 Almaty, Kazakhstan

${ }^{6}$ Faculty of Engineering, Beirut Arab University, Beirut, Lebanon

\begin{abstract}
This paper reports a study on producing admixtures from chitosan (Ch) obtained from shrimp shell treatment. The admixtures (Ch-g-AA) were based on chitosan (Ch) and acrylic acid (AA) in the following composition ratios: 65/35, 50/50, and 35/65. The grafted copolymers were synthesized using grafting polymerization and potassium persulphate as the initiator. This study investigated the properties of mortars in the presence of grafted copolymers, including setting time, workability, water absorption, and compressive strength. The results showed that grafted copolymers premixed with mortar mixes improved the properties of the mortar. However, increasing the AA ratio in the grafted copolymer decreased the $\mathrm{W} / \mathrm{C}$ ratio, setting time, and water absorption, whereas the fluidity and compressive strength increased.
\end{abstract}

Keywords: Acrylic acid; Chitosan; Copolymer; Grafted; Mortar

\section{Introduction}

At present, research in the field of admixtures for construction materials based on polymeric compounds has gained increasing significance and attention (Ariffin et al., 2015; $\mathrm{Ke}, 2019)$. These compounds are used in various spheres as additives because they impart unique properties, including workability, compressive strength, durability, water/cement ratio, water absorption, and porosity (Mignon et al., 2016). Thus, polymers have become more monolithic regarding impermeability, frost resistance, and tensile strength. In addition, bending has increased in cement pastes, mortars, and concretes. Several researchers have investigated the effects of different polymers, including acrylic, polyurethane, epoxy, and chitosan, on the physicomechanical properties of cement pastes, mortars, and concretes (Negim et al., 2013; Bezerra, 2016; Bekbayeva, 2020a; 2020b). Chitosan (CS) is a polysaccharide composed of randomly distributed deacetylated ( $\beta-(1-4)$ - 
linked D-glucosamine) and acetylated units based on D-glucosamine (Pillai et al., 2009; Bezerra et al., 2011; Lasheras-Zubiate et al., 2011; Vyšvařil and Žižlavský, 2017). Polymeric resins are chosen according to mortar type based on several factors, including functional groups, polymer types, molar ratio, $\mathrm{pH}$, viscosity, and polymer dosage (Ukrainczyk and Rogina, 2013; Govin et al., 2016; Wuju et al., 2020). The presence of amino groups in chitosan enables its use in many applications, including bio cement, dental bio cement, and additives to cement-based materials. The effects of chitosan and chitosan derivatives on the properties of cements and mortars have been reported. For example, Lasheras-Zubiate et al. (2012) studied the effects of the addition of two nonionic chitosan derivatives (hydroxypropyl and hydroxyethyl chitosan) and one ionic derivative (carboxymethyl chitosan) on the properties of cement mortar. Ionic chitosan derivatives were more effective than nonionic derivatives, acted as good thickeners, and reduced the workability of cement mortar because of the delay in the hydration of cement particles. Ustinova and Nikiforova (2016) investigated the effects of hydroxypropyl chitosan on cementitious materials and found that viscosity and water retention values increased. However, when used in lime mortars, it showed the same results but with lower efficiency (Žižlavský et al., 2019). Yulia and Tamara (2016) reported that chitosan added to cement did not reduce the cement's strength compared with a synthetic polymer additive based on polyethylhydrosiloxan. In addition, the amount of chitosan (0.6-1.0\% based on cement mass) increased the resistance of the cement compositions to alternate freezing and thawing. Bezerra et al. (2011) reported that the utilization of chitosan as an admixture in cement paste reduced porosity, increased viscosity, and improved strength, whereas the addition of chitosan had an adverse impact on the properties of the cement. Shenghua et al. (2014) reported that chitosan modified by amidation and sulfonation through a reaction with maleic anhydride had a high water-reducing ratio, fluidity, and compressive strength at a low water/cement ratio. With the addition of latex and chitosan to concrete, compressive and tensile strengths decreased by $14 \%$ and $24 \%$, respectively, compared with the control (Ulisses et al., 2011). The primary mechanism of the action of polymer additives in cement systems is that they form a polymer film on the surface of the grains of cement, sand, and capillaries, which promotes the adhesion of sand to cement particles (Negim et al., 2013; Santos et al., 2018; Muntohar et al., 2020). Thus, polymers have become more monolithic regarding impermeability, frost resistance, tensile strength, and bending increases in cement paste, mortar, and concrete. Bekbayeva et al. (2020a) modified chitosan by grafting with acrylic acid in different ratios to clarify the effects of three different composition ratios of chitosan-g-acrylic acid, P[Ch-g-AA], on the physical and mechanical properties of cement pastes. They found that as the AA ratios in the grafted copolymer increased, the water-to-cement (WC) ratio, setting time, and water absorption decreased. In contrast, compressive strength sharply increased at almost all hydration ages. Their work was further extended to investigate the effects of modified chitosan on the properties of mortar, which is the subject of the present investigation.

\section{Materials and Methods}

\subsection{Materials}

Chitosan (88\% deacetylation) (Ch) was purchased from R \& M Marketing, UK. Acrylic acid (AA), glacial acetic acid, potassium persulphate 98\% (KPS), isopropanol alcohol, N, Ndimethylformamide (DMF), barium chloride, and sulfuric acid were purchased from SigmaAldrich. All chemicals were used without further purification. Portland cement (PC) (Portland cement clinker PCC, wt.\% and gypsum (G, 4 wt.\%) was used in this study. The PC conformed to EN 197-1 (2011). The mineralogical composition of the PC sample was $\mathrm{C}_{3} \mathrm{~S}$, 
$58.79 \% ; \beta-\mathrm{C}_{2} \mathrm{~S}, 17.68 \% ; \mathrm{C}_{3} \mathrm{~A}, 8.08 \% ; \mathrm{C}_{4} \mathrm{AF}, 9.72 \%$, as shown in Table 1 . Sand $0.21-0.53$ $\mathrm{nm}$ ) was used as a fine aggregate free from organic or clay-like materials, which was in compliance with class M of BS 882 (2016).

Table 1 Chemical composition of Portland cement, mass \%

\begin{tabular}{cccccccccc}
\hline $\begin{array}{c}\text { Oxides } \\
\text { Materials }\end{array}$ & $\mathrm{SiO}_{2}$ & $\mathrm{Al}_{2} \mathrm{O}_{3}$ & $\mathrm{Fe}_{2} \mathrm{O}_{3}$ & $\mathrm{CaO}$ & $\mathrm{MgO}$ & $\mathrm{SO}_{3}$ & $\mathrm{Na}_{2} \mathrm{O}$ & $\mathrm{K}_{2} \mathrm{O}$ & \multirow{2}{*}{ L.O.I } \\
\hline $\mathrm{PCC}$ & 21.48 & 6.03 & 4.22 & 64.29 & 0.68 & 0.39 & 0.21 & 0.11 & 1.32 \\
$\mathrm{G}$ & 0.58 & 0.14 & 0.11 & 30.08 & 0.13 & 45.36 & 0.07 & 0.09 & 22.16 \\
\hline
\end{tabular}

\subsection{Synthesis and Characterization of Grafted Copolymers}

Graft copolymers based on chitosan (Ch) and acrylic acid (AA) were synthesized with various ratios of AA: M1: (65: 35); M2: (50: 50); and M3: (35: 65). Potassium persulphate (KPS) was the initiator, and acetic acid solution (1\% v/v) was the solvent at $60^{\circ} \mathrm{C}$ for $3 \mathrm{~h}$. The preparation of grafted copolymers and methods of analysis (FT-IR, TGA, DSC, and SEM) have been reported by Bekbayeva et al. (2020a). The various compositions of monomers in the grafted copolymers and the main properties of the obtained grafted copolymers are presented in Table 2. The chemical structure of the modified chitosan is shown in Figure 1.

Table 2 Properties of P(Ch-g-AA) (Bekbayeva et al., 2020a)

\begin{tabular}{cccccc}
\hline No. & Ch & AA & $T_{g}\left({ }^{\circ} \mathrm{C}\right)^{\mathrm{a}}$ & IDT $_{\max }\left({ }^{\circ} \mathrm{C}\right)^{\mathrm{b}}$ & Appearance \\
\hline M1 & 35 & 65 & 77.23 & 230 & \\
M2 & 50 & 50 & 93.91 & 230 & Liquid \\
M3 & 65 & 35 & 104.3 & 320 & \\
\hline
\end{tabular}

aDetermined from DSC curves

bDetermined from the derivative of TGA

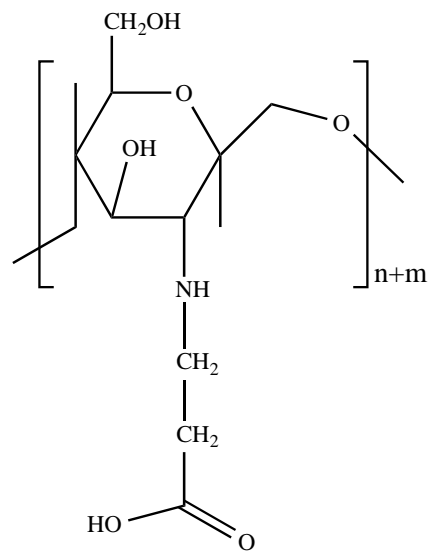

Figure 1 Chemical structure of $\mathrm{P}(\mathrm{Ch}-\mathrm{g}-\mathrm{AA})$

\subsection{Mixing and Testing}

Mortar specimens of $70 \mathrm{~mm}^{3}$ were prepared in three groups. The control mix (M0) consisted of Portland cement (PC), sand, and water. In mixes M1-M3, the prepared admixtures (grafted copolymer) were added, and the addition rate was $2 \%$ by the weight of the cement. The proportion of cement to sand was 1:3 (by weight), the water/cement ratio $(\mathrm{W} / \mathrm{C})$ was 0.525 , and no admixtures (i.e., grafted copolymer) were added. The cement-to-sand ratio was kept constant. However, the water-to-cement ratio was changed so that the same consistency was achieved. Further details about the mixes are shown in Table 3. The effects of grafted copolymers at different composition ratios of $\mathrm{Ch}$ and AA on 
the $\mathrm{W} / \mathrm{C}$ ratio of mortar mixes are shown in Figure 2. The $\mathrm{W} / \mathrm{C}$ ratio of mortar was reduced from 0.525 to 0.44 , and the AA in the grafted copolymer ratio increased from $35 \%$ to $65 \%$.

Table 3 Admixtures used in mortar mixes

\begin{tabular}{cc}
\hline Mix & $\begin{array}{c}\text { Admixtures } \\
\text { P(Ch/AA) }\end{array}$ \\
\hline M0 & -- \\
M1 & $65 / 35$ \\
M2 & $50 / 50$ \\
M3 & $35 / 65$ \\
\hline
\end{tabular}

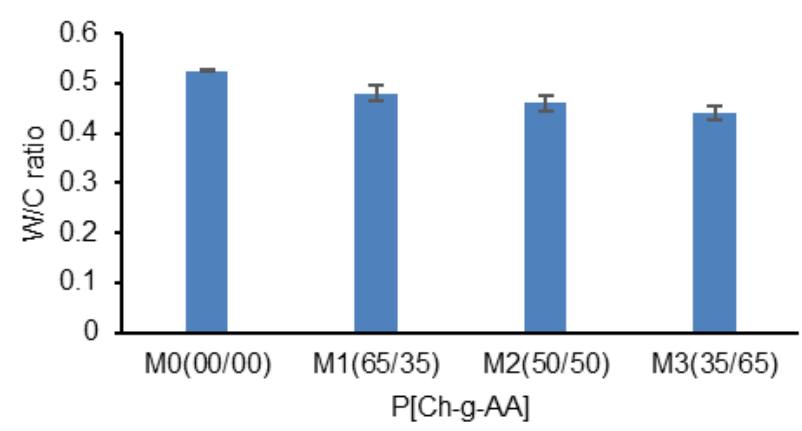

Figure 2 W/C ratio of mortar premixed with grafted copolymer $\mathrm{P}(\mathrm{Ch}-\mathrm{g}-\mathrm{AA})$

The cement and sand were intermixed until homogeneity was achieved. Then the surfactants or prepared latexes were added to the mixing water, which was then added gradually to the cement/sand mixture to determine the water consistency (ASTM C 187, 2016) and setting time using a Vicat apparatus (ASTM C 191, 2019). A workability test using a flow table was conducted according to BS EN 12350-5 (2019). The resulting mortar was placed directly into $70 \mathrm{~mm}^{3}$ stainless steel molds. The molds were manually agitated for 2 min and then placed on a vibrator for another $2 \mathrm{~min}$. The molds were kept in a humidity chamber at $100 \%$ R.H. and a constant room temperature overnight and then demolded and cured under water until testing. The testing, which included compressive strength (ASTM C109/ C109M-16a, 2016) and water absorption (BS 1881-122, 2011), was conducted at 3, 7 , and 28 days.

\section{Results and Discussion}

\subsection{Grafted Copolymer's Structure}

The IR spectra of chitosan and grafted chitosan with acrylic acid are shown in Figure 3. The $\mathrm{O}-\mathrm{H}$ bending, $\mathrm{C}-\mathrm{H}$ stretch, $\mathrm{N}-\mathrm{H}$ bend, $\mathrm{C}-\mathrm{N}$ stretch, and the $\mathrm{C}-\mathrm{O}-\mathrm{C}$ bridge were at 1,050 $\mathrm{cm}^{-1}, 2,922 \mathrm{~cm}^{-1}, 1,635 \mathrm{~cm}^{-1}, 1,384 \mathrm{~cm}^{-1}$, and 1,111 $\mathrm{cm}^{-1}$ of pure chitosan (Ch), respectively (Pradeep et al., 2012; Ghosh et al., 2014; Khalil et al., 2015; Li et al., 2020). Additionally, a strong peak at 3,436 $\mathrm{cm}^{-1}$ could be attributed to the $\mathrm{O}-\mathrm{H}$ stretch, the extension vibration of $\mathrm{N}-\mathrm{H}$, and interhydrogen bonds of the polysaccharide, as shown in Figure 3a. The IR spectra of $\mathrm{P}(\mathrm{Ch}-\mathrm{g}-\mathrm{AA})$ showed new absorption peaks that appeared at 1,565 $\mathrm{cm}^{-1}$, and 1,544 $\mathrm{cm}^{-1}$ corresponded to $\mathrm{C}=\mathrm{O}$ and $\mathrm{N}-\mathrm{H}$ due to the acrylic acid grafted onto the chitosan, as shown in Figure $3 b$. Peaks at $1,219 \mathrm{~cm}^{-1}$ and $1,264 \mathrm{~cm}^{-1}$ corresponded to the $\mathrm{C}-0$ stretch of the AA. A strong peak at $3,500 \mathrm{~cm}^{-1}$ was attributed to the $\mathrm{O}-\mathrm{H}$ stretch vibration of the $\mathrm{AA}, \mathrm{N}-\mathrm{H}$ vibration, and intermolecular $\mathrm{H}$-bonds. Peaks at 1,459 $\mathrm{cm}^{-1}$ and 1,433 $\mathrm{cm}^{-1}$ indicated an $\mathrm{OH}$ bend of the AA, which further confirmed the grafted polymerization process (Kusrini et al., 2015), as shown in Figure 4. The properties of $\mathrm{P}(\mathrm{Ch}-\mathrm{g}-\mathrm{AA})$ were investigated by Bekbayeva et al. (2020a). 


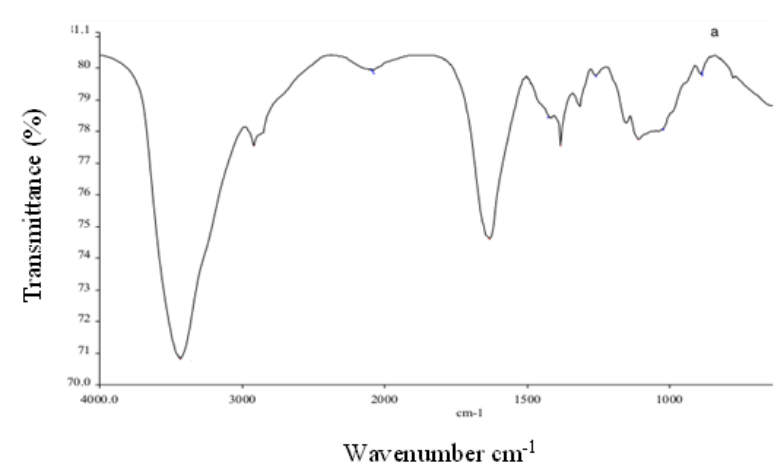

(a)

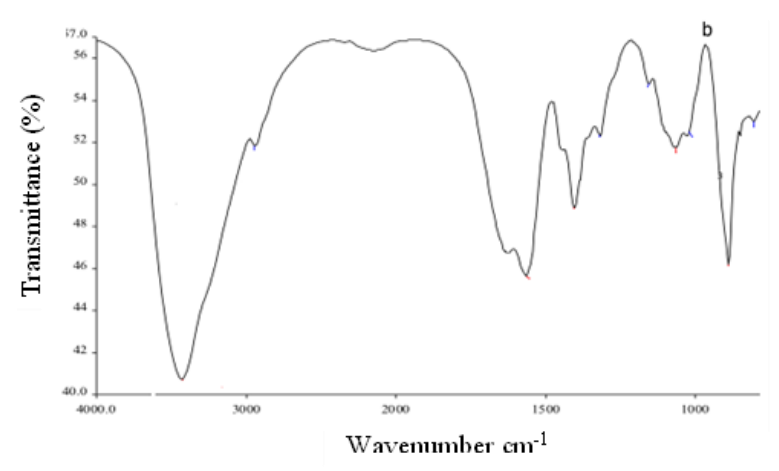

(b)

Figure 3 IR spectra of: (a) Ch; and (b) P(Ch-g-AA)

Initiation

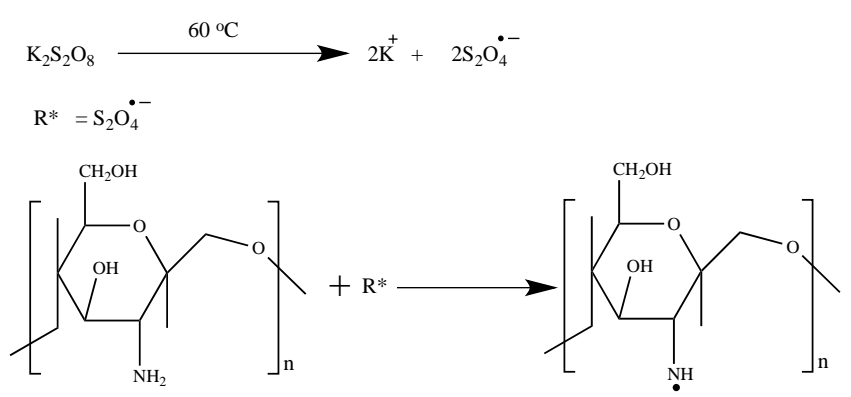

Propagation

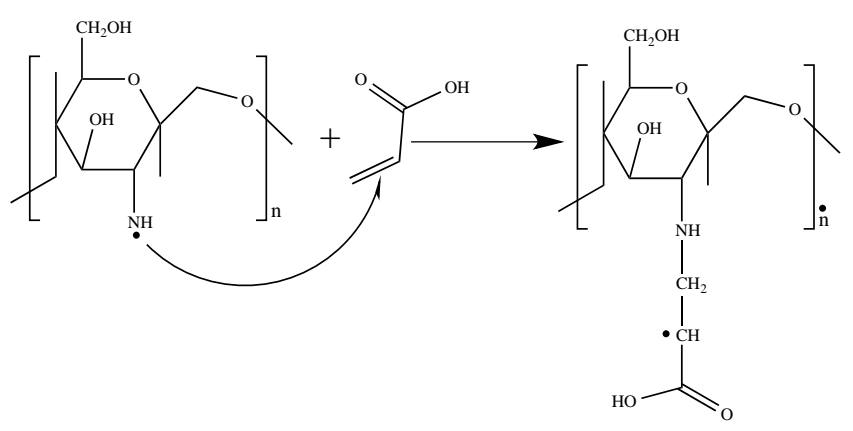

Termination

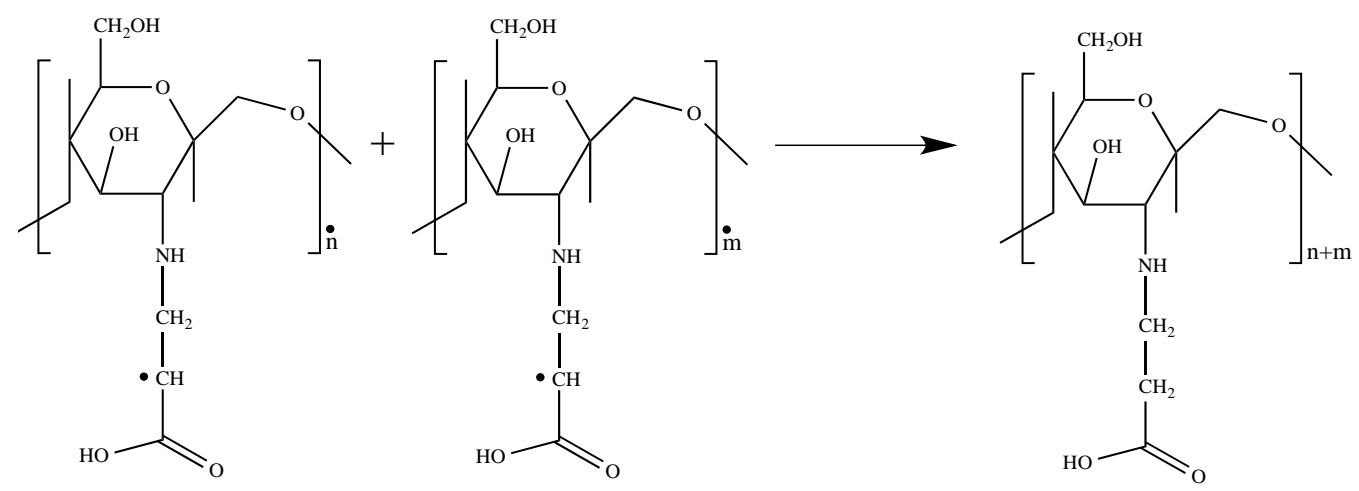

Figure 4 Scheme of the mechanism of AA grafted onto Ch

\subsection{Setting Time}

Figure 5 shows the evolution setting times (initial and final) of the mortar versus the various composition ratios of $\mathrm{Ch}$ and $\mathrm{AA}$ in the copolymers. The results showed that the 
setting times of mortar premixed with copolymer were retarded. The reason is that the type and content of the carboxylic acid group influenced the retarding side effect on the mortar mixes (Guo et al. 2018; Fang, 2018). However, by increasing the AA ratio in the grafted copolymer, the initial and final setting times of mortar decreased.

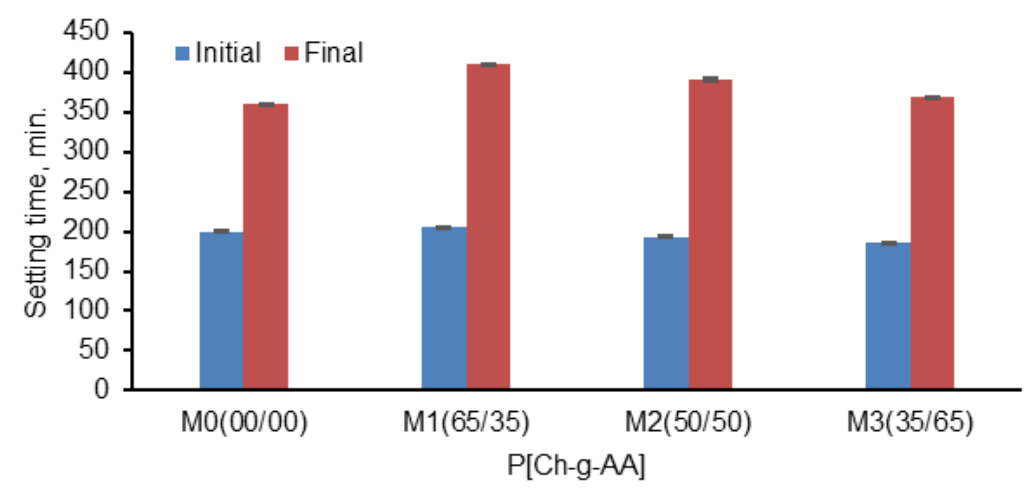

Figure 5 Setting time of mortar premixed with grafted copolymer $\mathrm{P}(\mathrm{Ch}-\mathrm{g}-\mathrm{AA})$

\subsection{Workability}

Figure 6 displays mortar workability in the presence of a 2\% grafted copolymer. The fluidity of the mortar increased with the addition of the grafted copolymer. The branched backbone in the structure of the grafted copolymer had a steric hindrance effect that improved the dispersion of the cement (Fang, 2018). As the ratio of AA increased, the workability of the mortar increased. The mortar mix containing 65/35 P(Ch-g-AA) showed the highest workability $(250 \mathrm{~mm})$, while the mortar containing 35/65 P(Ch-g-AA) showed the highest workability (208 mm).

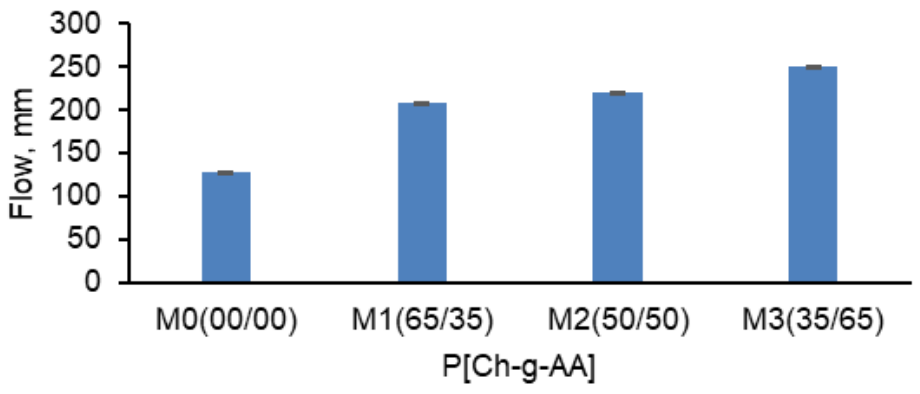

Figure 6 Workability of mortar premixed with grafted copolymer P(Ch-g-AA)

Generally, the factors that affect mortar workability include the amount of cement, the shape of fine and coarse aggregates, the admixture, and the W/C ratio (Juntao et al., 2017). In this study, the workability of the mortar mixed with the grafted polymer was measured as a function of the $\mathrm{W} / \mathrm{C}$ ratio, as illustrated in Figure 7. The workability of the mortar premixed with the grafted copolymer increased as the $\mathrm{W} / \mathrm{C}$ ratio decreased. However, the increase in workability $(250 \mathrm{~mm})$ was relatively greater at $\mathrm{M} 3$ with a lower $\mathrm{W} / \mathrm{C}$ ratio (0.443).

\subsection{Water Absorption}

Figure 8 shows that the absorption rate of water premixed with grafted copolymer decreased compared with the control mixes at increased curing times of 3-28 days. Generally, the water absorption by the mortars decreased as the curing time increased from 3 to 28 days. This was attributed to the continual hydration process and consistency of hydration products, which were deposited into the pores of the hardened cement, thus 
leading to a reduction in water absorption (Kim et al., 2014; Fang, 2018). The addition of grafting copolymer to mortar exhibited lower water absorption compared with the control (M0). This result was attributed to the effect of grafted copolymers on the hydration process at an early stage, which increased hydration. However, as the AA ratio in the grafted copolymer increased, the rate of water absorption decreased.

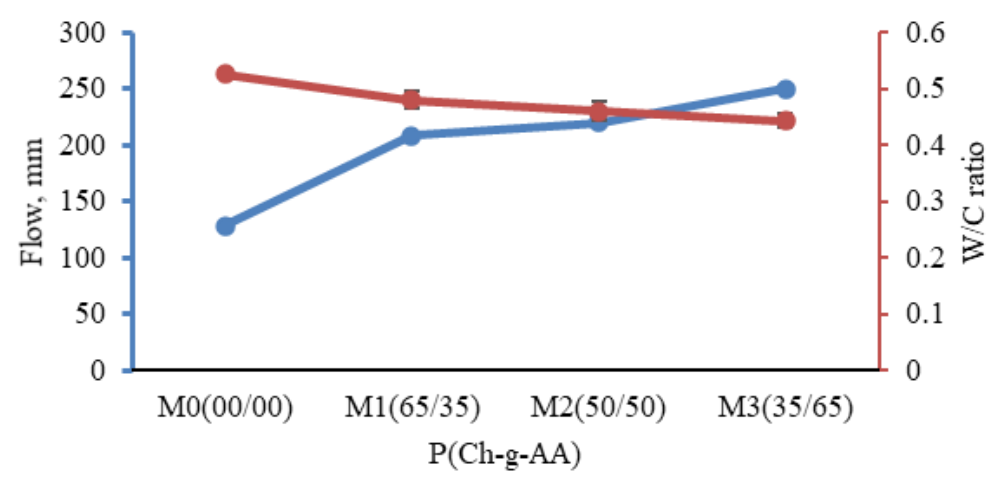

Figure 7 Relationship between W/C ratio and workability of mortar premixed with grafted copolymer P(Ch-g-AA)

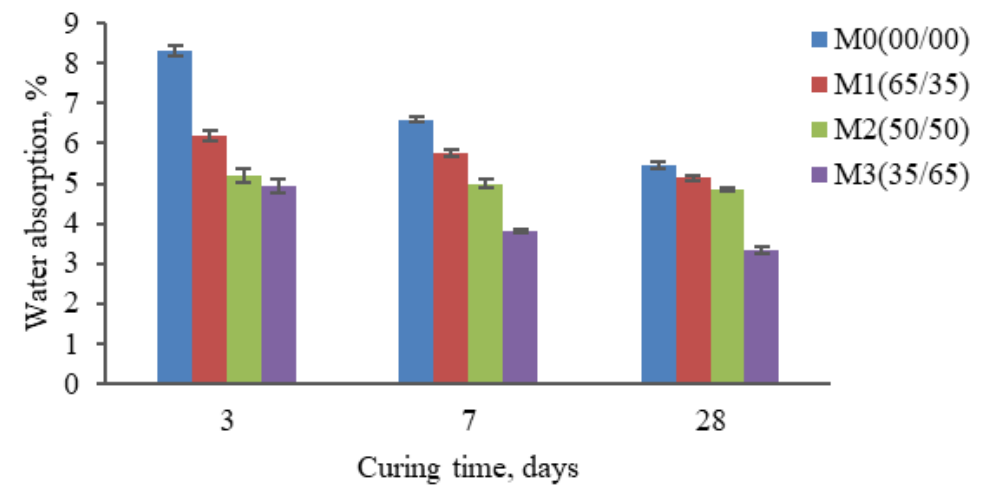

Figure 8 Water absorption of mortar in the presence of grafted copolymer P(Ch-g-AA)

\subsection{Compressive Strength}

The effects of the grafted copolymers on the compressive strength of the mortar mixes are presented in Figure 9. The results revealed that the compressive strength of mortar significantly increased as the curing increased from 3-28 days. This result might have been due to the film polymer formed on the cement surface, which filled the mortar pores and improved the compressive strength (Negim et al., 2014; 2015; Ke, 2019). As the AA ratio increased from $35 \%$ to $65 \%$ in the grafted copolymer, the compressive strength of the mortar increased from $41.28 \mathrm{MPa}$ to $46.55 \mathrm{Mpa}$. The reason is that the grafted copolymers promoted the hydration process and improved the strength of the cement at an early stage. Significant factors that affect compressive strength mortar include the ratio of water to cement, the ratio of sand to cement, and the strength class of cement (Moodi et al., 2018). Moreover, the compressive strength of the mortar premixed with grafted polymer increased gradually as the $\mathrm{W} / \mathrm{C}$ ratio decreased, as shown in Figure 10. Mortar with the $\mathrm{W} / \mathrm{C}$ ratio of 0.525 gave the lowest compressive strength $(39.6 \mathrm{Mpa})$, whereas mortar premixed with grafted polymer M3 and a W/ C ratio of 0.443 gave the highest compressive strength (46.98 Mpa). Typically, the relationship between compressive strength and W/C ratio is inversely proportional (Moodi et al., 2018; Ke, 2019). A typical relationship between compressive strength and the absorption rate of water premixed with grafted copolymer at 
28 days of curing is shown in Figure 11. Compressive strength was found to increase as water absorption decreased at 28 days. In addition, grafted copolymer in the mortar mixes decreased water absorption from 5.45\% M0 (00/00) to 3.35\% M3 (35/65). The lower the water absorption, the higher the compressive strength of the mortar mixes (Łukowski et al., 2015; Athiyamaan and Ganesh, 2019).

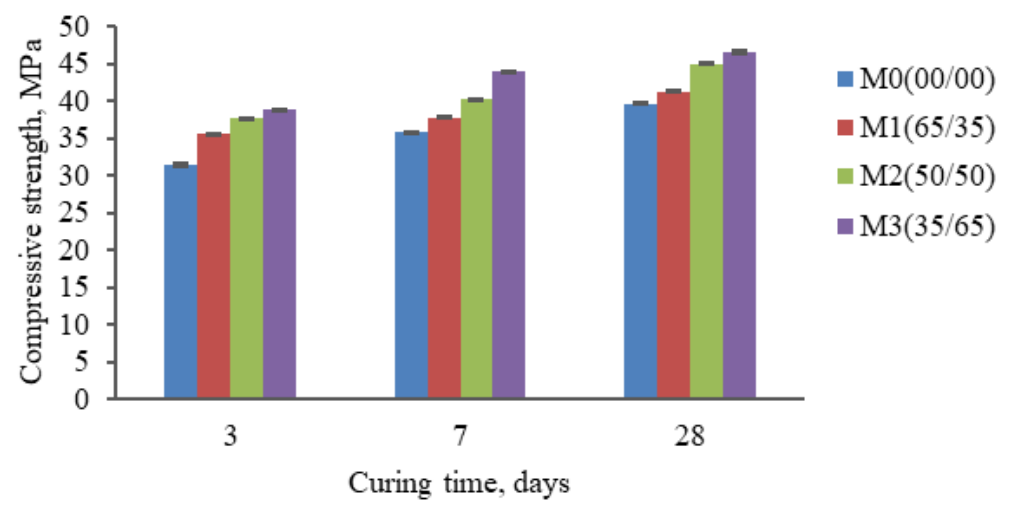

Figure 9 Compressive strength of mortar in the presence of grafted copolymer $\mathrm{P}(\mathrm{Ch}-\mathrm{g}-\mathrm{AA})$

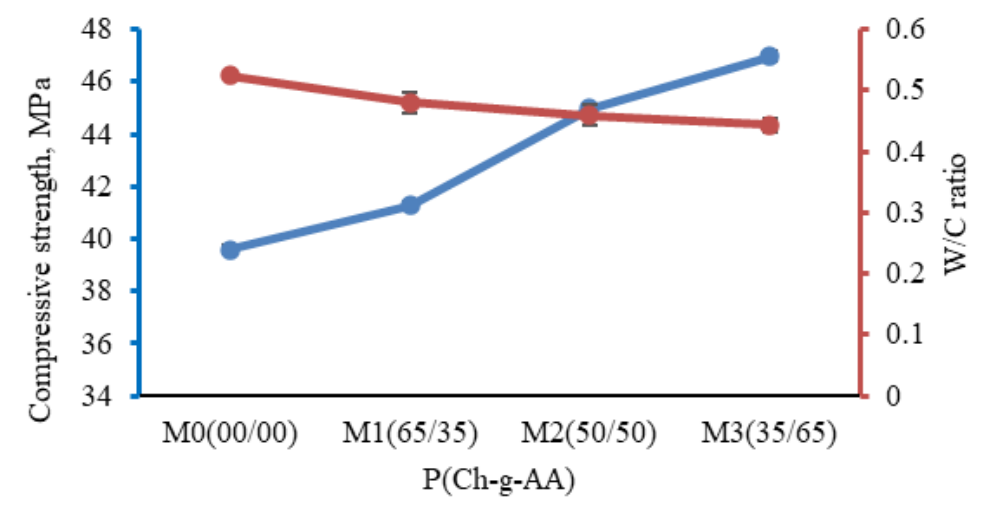

Figure 10 Relationship between $\mathrm{W} / \mathrm{C}$ ratio and compressive strength of mortar premixed with grafted copolymer $\mathrm{P}(\mathrm{Ch}-\mathrm{g}-\mathrm{AA})$ at 28 days

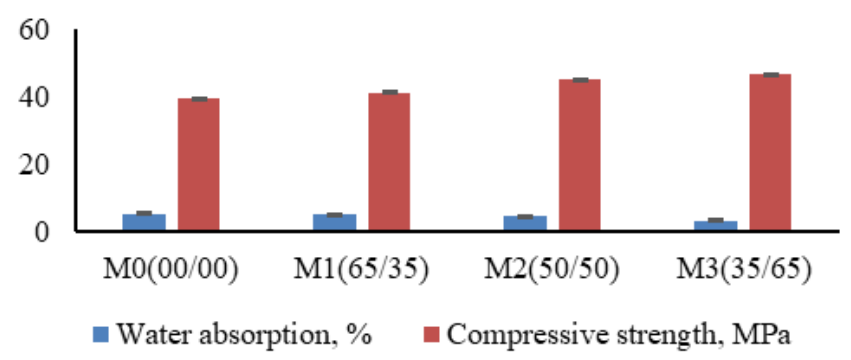

Figure 11 Relationship between compressive strength and water absorption of mortar premixed with grafted copolymer $\mathrm{P}(\mathrm{Ch}-\mathrm{g}-\mathrm{AA})$ at 28 days

\section{Conclusions}

The properties of mortar containing grafted copolymers were investigated. The grafted copolymers were based on the different composition ratios of $\mathrm{Ch}$ and AA. The results showed that the $\mathrm{W} / \mathrm{C}$ ratio decreased as the AA ratio increased in the grafted copolymers. The compressive strength and workability of mortar premixed with grafted copolymers increased in the $\mathrm{OH}, \mathrm{NH}$, and $\mathrm{COOH}$ groups, and branched chains pierced the liquid phase to disperse the effects of copolymer particles among the cement particles. In addition, the 
setting times (initial and final) were lengthened, while water absorption decreased as the AA ratio increased in the grafted copolymers.

\section{References}

Athiyamaan, V., Ganesh, G.M., 2019. Analysis of the Alignment of Micro-Steel Fibers in Admixture-Based Self-Compacting Concrete (MSFR-SCC) using NDT and Evaluation of Its Effect on the Modulus of Rupture. International Journal of Technology, Volume 10(1), pp. $5-15$

Ariffin, N.F., Hussin, M.W., Sam, A.R.M., Bhutta, M.A.R., Khalid, N.H.A., Mirza, J., 2015. Strength Properties and Molecular Composition of Epoxy-Modified Mortars. Constr. Build. Mater, Volume 94, pp. 315-322

ASTM C187, 2016. American Standard Test Method

ASTM C191, 2019. American Standard Test Method

ASTM C109/C109M-16a, 2016. Standard Test Method for Compressive Strength of Hydraulic Cement Mortars (Using 2-in. or [50-mm] Cube Specimens). ASTM International: West Conshohocken, PA, USA

Bekbayeva, L., Negim, E.S., Yeligbayeva, G., Ganjian, E., 2020a. Modification of Chitosan as Chemical Admixture for Cement Pastes. Egyptian Journal of Chemistry, Volume 63(4), pp. 1497-1508

Bekbayeva, L., Negim, E., Gulzhakhan, Y., Ganjian, E., 2020b. Utilization of Poly(Polyvinyl Alcohol-g-2-Ethylhexyl Acrylate) as Admixture for Mortar. International Journal of Technology, Volume 11(2), pp. 259-268

BS 882, 2016. British Standard Test. Aggregate for Concrete

BS EN 12350-5, 2019. British Standard Test. Method for Determination of Flow

BS 1881-122, 2011. British Standard Test. Testing Concrete: Method for Determination of Water Absorption

Bezerra, U.T., 2016. Biopolymers with Superplasticizer Properties for Concrete. In: Biopolymers and Biotech Admixtures for Eco-Efficient Construction Materials. Woodhead Publishing Limited: Cambridge, United Kingdom, pp. 195-220

Bezerra, U.T., Ferreira, R.M., Castro-Gomes, J.P., 2011. The Effects of Latex and Chitosan Biopolymer on Concrete Properties and Performance. Key Engineering Materials, Volume 466, pp. 37-46

EN 197-1, 2011. British Standard Test. Cement, Composition, Specifications and Conformity Criteria for Common Cements

Fang, Y., 2018. Study on Effects of Molecular Structure of Polycarboxylate Superplasticizer on Adsorption and Hydration Properties. New Building Materials Mag., Volume 45, pp. 14-17

Guo, S., Lu, Y., Bu, Y., Li, B., 2018. Effect of Carboxylic Group on the Compatibility with Retarder and the Retarding Side Effect of the Fluid Loss Control Additive Used in Oil Well Cement. Royal Society Open Science, Volume 5(9), pp. 1-9

Govin, A., Bartholin, M.-C., Biasotti, B., Giudici, M., Langella, V., Grosseau, P., 2016. Modification of Water Retention and Rheological Properties of Fresh State Cementbased Mortars by Guar Gum Derivatives. Construction and Building Materials, Volume 122, pp. 772-780

Ghosh, P., Rameshbabu, A.P., Dogra, N., Dhara, S., 2014. 2,5-dimethoxy 2,5-dihydrofuran Crosslinked Chitosan Fibers Enhance Bone Regeneration in Rabbit Femur Defects. RSC Advances, Volume 4(37), pp. 19516-19524

Juntao, D., Jun, Z., Zhaohua, D., 2017. Effect of Superabsorbent Polymer on the Properties of Concrete. Polymer, Volume 9(12), pp. 1-17 
Ke, Y., 2019. Preparation and Characterization of Early Strength Fast-setting Polycarboxylic Acid Water Reducer. New Building Materials Mag., Volume 8, pp. 5-8

Khalil, E.S., Saad, B., Negim, E.S.M., Saleh, M.I., 2015. Novel Water-soluble Chitosan Derivative Prepared by Graft Polymerization of Dicyandiamide: Synthesis, Characterisation, and Its Antibacterial Property. Journal of Polymer Research, Volume 22(6), pp. 1-12

Kusrini, E., Shiong, N.S., Harahap, Y., Yulizar, Y., Dianursanti, Arbianti, R., Pudjiastuti, A.R., 2015. Effects of Monocarboxylic Acids and Potassium Persulfate on Preparation of Chitosan Nanoparticles. International Journal of Technology, Volume 6(1), pp. 11-21

Kim, Y.Y., Lee, K.M., Bang, J.W., Kwon, S.J., 2014. Effects of W/C Ratio on Durability and Porosity in Cement Mortar with Constant Cement Amount. Advance in Material Science and Engineering, Volume 2014, pp. 1-11

Lasheras-Zubiate, M., Navarro-Blasco, I., Fernández, J.M., Álvarez, J.I., 2011. Studies on Chitosan as an Admixture for Cement-based Materials: Assessment of Its Viscosity Enhancing Effect and Complexing Ability for Heavy Metals. Journal of Applied Polymer Science, Volume 12, pp. 242-252

Li, M., Liu, J., Hu, Y., Gao, X., Yuan, Q., Zhao, F., 2020. Investigation of the Specularite/Chlorite Separation using Chitosan as a Novel Depressant by Direct Flotation. Carbohydrate Polymers, Volume 240, https://doi.org/10.1016/j.carbpol.2020.116334

Lasheras-Zubiate, M., Navarro-Blasco, I., Fernández, J.M.M., Álvarez, J.I.I., 2012. Effect of the Addition of Chitosan Ethers on the Fresh State Properties of Cement Mortars. Cement and Concrete Composites, Volume 34, pp. 964-973

Łukowski, P., Woyciechowski, P., Adamczewski, G., Rudko, M., Filipek, K., 2015. Curing of Polymer-Cement Concrete: Search for a Compromise. Advanced Materials Research, Volume 1129, pp. 222-229

Mignon, A., Snoeck, D., D’Halluin, K., Balcaen, L., Vanhaecke, F., Dubruel, P., Van Vlierberghe, S., De Belie, N., 2016. Alginate Bi-opolymers: Counteracting the Impact of Superabsorbent Polymers on Mortar Strength. Construction and Building Materials, Volume 110, pp. 169-174

Moodi, F., Kashi, A., Ramezanianpour, A.A., Pourebrahimi, M., 2018. Investigation on Mechanical and Durability Properties of Polymer and Latex-Modified Concretes. Construction and Building Materials, Volume 191, pp. 145-154

Muntohar, A.S., Diana, W., Tafalas, M.Y., Bimantara, N.R., 2020. The Behavior of the Flexible Plate - Supported with SiCC-Mortar Column on Expansive Soil. International Journal of Technology, Volume 11(1), pp. 123-132

Negim, E.S., Khatib, M.J., Nurlan, O.I., 2013. Effect of Acrylate Copolymers on the Rheological Properties of Portland Cement Mortar Pastes, Part III. World Applied Sciences Journal, Volume 23(4), pp. 549-553

Negim, E.S., Aisha, A.M.B., Yessimkanova, U., Kurmanbekova, A., Tyazhina, K., Urkimbaeva, P.I., Rakhmetullayeva, R.K., Shatabayeva, E., Irmukhametova, G., Mun, G.A., Yeligbayeva, G. Zh., Khatib, J.M., 2015. The Effect of Terpolymer Admixtures on Physico-mechanical Properties of Cement Pastes. International Journal of Basic and Applied Sciences, Volume 4(1), pp. 10-18

Negim, E.S., Khatib, J.M., Sakhy, M., Shilibekov, S., Shanshabayev, N., Jakiyayev, B., 2014. The Effect of pH on Physico-Mechanical Properties of Cement Pastes Containing Poly (Acrylate) Latexes: Chemical Admixtures. World Applied Sciences Journal, Volume 29(6), pp. 796-804

Pillai, C.K.S., Paul, W., Sharma, C.P., 2009. Chitin and Chitosan Polymers: Chemistry, Solubility and Fiber Formation. Progress in Polymer Science, Volume 34, pp. 641-678 
Pradeep, K., Yahya, E.C., Lisa, C.D.T., Girish, M., Dinesh, N., Viness, P., 2012. Novel HighViscosity Polyacrylamidated Chitosan for Neural Tissue Engineering: Fabrication of Anisotropic Neurodurable Scaffold via Molecular Disposition of Persulfate-Mediated Polymer Slicing and Complexation. International Journal of Molecular Sciences, Volume 13, pp. 13966-13984

Santos, A.R., Veiga, M.D.R., Santos Silva, A., de Brito, J., Álvarez, J.I., 2018. Evolution of the Microstructure of Lime-based Mortars and Influence on the Mechanical Behaviour: The Role of the Aggregates. Construction and Building Materials, Volume 187, pp. 907-922

Shenghua, L., Jingjing, L., Qingfang, Z., Huang, L., Sun, T., 2014. Synthesis of Modified Chitosan Superplasticizer by Amidation and Sulfonation and Its Application, Performance and Working Mechanism. Industrial \& Engineering Chemistry Research, Volume 53, pp. 3908-3916

Ustinova, Y.V., Nikiforova, T.P., 2016. Cement Compositions with the Chitosan Additive. Procedia Engineering, Volume 153, pp. 810-815

Ulisses, T.B., Rui, M.F., João, P.-G., 2011. The Effect of Latex and Chitosan Biopolymer on Concrete Properties and Performance. Key Engineering Materials, Volume 466, pp. $37-$ 46

Ukrainczyk, N., Rogina, A., 2013. Styrene-butadiene Latex Modified Calcium Aluminate Cement Mortar. Cement and Concrete Composites, Volume 41, pp. 16-23

Vyšvařil, M., Žižlavský, T., 2017. Effect of Chitosan Ethers on Fresh State Properties of Lime Mortars. In: IOP Conference Series. Materials Science and Engineering, Bristol, Volume 251(1), pp. 1-8

Wuju, X., Changlong, W., Xuefei, L., Jiye, L., Desheng, X., Yang, L., 2020. Effect of Functional Superplasticizers on Concrete Strength and Pore Structure. Applied Sciences, Volume 10(10), pp. 1-16

Yulia, V.U., Tamara, P.N., 2016. Cement Compositions with the Chitosan Additive. Procedia Engineering, Volume 153, pp. 810-815

Žižlavský, T., Vyšvařil, M., Bayer, P., Rovnaníková, P., 2019. Impact of Guar Gum and Chitosan Ethers on Physico-mechanical Properties and Durability of Natural Hydraulic Lime Mortars. In: Proceedings of the $5^{\text {th }}$ Historic Mortars Conference. RILEM Publications S.A.R.L.: Paris, France, pp. 1279-1290 